\title{
HUKUM WAKAF BENDA BERGERAK (UANG) MENURUT FATWA ULAMA DAN UNDANG-UNDANG NOMOR 41 TAHUN 2014 TENTANG WAKAF
}

\author{
Boedi Abdullah \\ STAI Syamsul 'Ulum \\ Email : boediabdullah@gmail.com
}

\begin{abstract}
This research has found two results. First, Moslem scholars have different opinions about the legal status of endowments on movable assets. The Hanafiyah scholars do not allow endowments of movable assets in all forms. Instead, the scholars of Malikiyah allow the endowments of movable assets in all forms. The Shafi'ites scholars and Hanabilah falls somewhere between the two opinions, they allow the endowments of movable assets except in form of money. Secondly, Article 16, paragraph 2-3 of the Act Number 41 of 2004 on Endowments especially concerning endowments of movable assets which includes money, precious metals, securities, vehicles, intellectual property rights, the right to lease and other movable assets is strongly influenced by the Malikiyah scholars' opinion.
\end{abstract}

Keywords : endowments, movable assets, Hanafiyah, Malikiah, Syafi'iyah, Hanabilah

\begin{abstract}
Abstrak
Penelitian ini menghasilkan dua temuan. Pertama, para ulama madzhab berbeda pendapat tentang hukum wakaf benda bergerak. Para Ulama Hanafiyah, tidak membolehkan wakaf benda bergerak dalam segala bentuknya. Sebaliknya, para Ulama Malikiyah membolehkan wakaf benda bergerak dalam segala bentuknya. Para Ulama Syafi'iyah dan Hanabilah berada di antara kedua pendapat itu, membolehkan wakaf benda bergerak kecuali yang berbentuk uang. Kedua, pasal 16 ayat 2-3 Undang-Undang RI. Nomor 41 Tahun 2004 tentang Wakaf yang menyangkut wakaf benda berberak yang meliputi uang, logam mulia, surat berharga, kendaraan, hak atas kekayaan intelektual, hak sewa, dan benda bergerak lain sesuai dengan ketentuan Syariah dan peraturan perundang-undangan yang berlaku sangat dipengaruhi oleh pendapat para ulama Malikiyah.
\end{abstract}

Kata Kunci : wakaf, benda bergerak, Malikiyah, Hanafiyah, Syafi'iyah, Hanabilah

Pendahuluan

Mayoritas penduduk Indonesia (87,18 \%) adalah pemeluk Islam dari total penduduk 237.641.326 jiwa. ${ }^{1}$ Berdasarkan madzhab yang mereka anut sebagian besar dari mereka bermadzhab Syafi'i sebagaimana direpresentasikan oleh dominasi Nahdiyyin di

\footnotetext{
${ }^{1}$ Badan Pusat Statistik, "Penduduk Menurut Wilayah dan Agama yang Dianut". Sensus Penduduk 2010. Jakarta, Indonesia: Badan Pusat Statistik. 15 May 2010. Detail informasi tentant iniadalah: Islam $207176162(87,18 \%)$, Kristen $16528513(6,96)$, Katolik $6907873(2,91)$, Hindu $4012116(1,69)$, Buddha 1703254 $(0,72)$, Kong Hu Cu $117091(0,05)$, lainnya $299617(0,13)$, tidak terjawab $139582(0,06)$, tidak ditanyakan $757118(0,32)$, total 237641326 .
} 
seluruh provinsi berpenduduk mayoritas muslim yang secara resmi menetapkan madzhab Syafi'i sebagai pegangan dalam melaksanakan peribadatan baik mahdhah maupun ghair mahdhah seperti di Propinsi Jawa Barat, Jawa Tengah, Jawa Timur, dan Daerah Khusus Ibu Kota (DKI) Jakarta. Namun, dalam beberapa bidang muamalah yang sudah diatur dalam qanun, semua pemeluk madzhab di Indonesia tunduk ke dalam aturan yang sudah ada dalam qanun, seperti dalam masalah wakaf yang diatur dalam Undang-Undang No. 41 Tahun 2004 tentang Wakaf.

Undang-Undang No. 41 Tahun 2004 tentang Wakaf memiliki kekhasan tersendiri jika dikaitkan dengan karakteristik pengikut madzhab terbesar di Indonesia, terutama dalam pasal-pasal yang mengatur tentang hukum wakaf benda bergerak. Secara teoritis, di negara mana pun di dunia setiap undang-undang yang dikeluarkan oleh negara yang berhubungan dengan agama selalu mengikuti mainstream dari madzhab dominan di negara yang bersangkutan. Di Indonesia, dalam pasal-pasal yang mengatur tentang hukum wakaf benda bergerak ternya madzhab Syafi'i tidak dominan, bahkan menjadi pendapat yang "dikesampingkan". Sebaliknya, pendapat Ulama Malikiyah yang dalam aspek ritual merupakan madzhab minoritas di Indonesia, mewarnai pasal-pasal yang mengatur tentang hukum wakaf benda bergerak dalam peraturan perundang-undangan tentang wakaf di Indonesia.

Mengingat wakaf itu merupakan filantrofi Islam (Islamic Philanthrophy) ${ }^{2}$ yang perlu diberdayakan untuk kepentingan pendanaan umat, maka analisis mendalam tentang masalah ini harus selalu menjadi fokus perhatian dari para ahli hukum Islam. Sejarah Islam di Indonesia telah menunjukkan bahwa wakaf berperan penting dalam mendukung pendirian mesjid, pesantren, majlis taklim, sekolah, rumah sakit, panti asuhan, dan lembaga pendidikan, serta lembaga sosial Islam lainnya. Benda yang dapat diwakafkan bukan hanya tanah milik, melainkan juga dapat berupa benda milik lainnya, benda tetap yang disebut al-'aqr atau benda bergerak yang disebut al-musya'. ${ }^{3}$ Dalam hal ini, para ulama terkadang menggunakan istilah yang berbeda untuk maksud yang sama seperti Ibnu Hajar al-Asqalani menyebut benda tetap atau benda tidak bergerak dengan istilah ghayr al-manqûlat dan benda bergerak dengan sebutan al-manqûlat. ${ }^{4}$ Makalah ini akan menganalisis bagaimana hukum wakaf benda bergerak menurut para ulama madzhab dan membuktikan dominasi pendapat Ulama Malikiyah dalam per-

\footnotetext{
${ }^{2}$ Filantrofi (philanthropy) berasal dari bahasa Yunani, philos (cinta) dan anthropos (manusia). Secara etimologis, filantropi adalah konseptualisasi dari praktik memberi (giving), pelayanan (services) dan asosiasi (association) secara sukarela untuk membantu pihak lain yang membutuhkan sebagai ekspresi rasa cinta. Dalam Islam, konsep filantropi dikenal dalam istilah zakat, infak, sedekah, dan wakaf (Chaider S. Bamualim, Irfan Abu Bakar, Revitalisasi Filantropi Islam, (Jakarta: Pusat Bahasa dan Budaya UIN Syarif Hidayatullah. 2005), hlm. 3-5.

3 Juhaya S. Praja, Perwakafan di Indonesia: Sejarah, Pemikiran, Hukum, dan Perkembangannya, (Bandung: Yayasan Piara. 1997), hlm. 7.

${ }^{4}$ Ahmad bin Ali bin Hajar, Fath al-Bary, (t.t.: Syirkah Iqamat al-Din. t.th.), Juz VI, hlm. 57.
} 
aturan perundang-undangan tentang wakaf di Indonesia, khususnya pada pasal-pasal yang mengatur hukum wakaf benda bergerak berbentuk uang.

\section{Hukum Wakaf Benda Bergerak Menurut Ulama Hanafiyah}

Ulama Hanafiyah tidak membolehkan wakaf benda bergerak dengan alasan bahwa di antara syarat wakaf adalah ta'bid (untuk selamanya), sedangkan dalam wakaf benda bergerak syarat ini tidak terpenuhi. ${ }^{5}$ Menurut Ulama Hanafiyah syarat benda wakaf itu ada empat. ${ }^{6}$

Pertama, benda wakaf adalah harta yang memiliki nilai atau berharga dan tetap (tidak bergerak). Oleh karena itu, menurut Ulama Hanafiyah tidak sah wakaf dengan:

a. Sesuatu yang tidak berbentuk harta benda seperti wakaf manfaat tidak dengan bendanya, wakaf hak-hak kebendaan seperti hak umum, karena hak bukan harta benda;

b. Benda yang tidak berharga menurut syara seperti wakaf benda yang memabukkan dan buku-buku yang menyesatkan, karena tujuan wakaf tidak akan tercapai yakni kemanfaatan benda wakaf dan pahala bagi Wakif.

c. Benda bergerak, karena wakaf benda bergerak tidak abadi, sedangkan keabadian adalah syarat diperbolehkannya wakaf. Namun demikian, wakaf benda bergerak boleh dengan alasan ikut (tabi') pada benda tetap lainnya seperti wakaf jalan, karena jalan ikut pada tanah, juga karena istihsan bi al-'urf seperti wakaf kitab dan seperangkat alat untuk janazah.

d. Pakaian besi dan alat senjata untuk perang, karena benda tersebut adalah benda bergerak dan tidak ada kebiasaan (adat) wakaf benda tersebut. Namun demikian, Abu Yusuf dan Muhammad dari kalangan Ulama Hanafiyah membolehkannya bahkan boleh menjual benda wakaf yang sudah rusak dan tidak bermanfaat lagi untuk dibelikan kembali pada benda yang sepadan.

Kedua, harta wakaf harus diketahui ukurannya atau satuannya seperti wakaf tanah $1.000 \mathrm{~m}^{2}$. Dengan demikian, tidak sah mewakafkan benda yang tidak diketahui.

Ketiga, harta benda wakaf adalah milik waqif sepenuhnya, bukan benda yang masih dalam khiyâr. Tidak sah wakaf benda yang masih dalam waktu khiyâr, karena benda tersebut dimiliki namun bukan pemilikan yang sempurna.

Keempat, benda wakaf adalah benda yang terpisah (tersendiri), karena di antara syarat diperbolehkan wakaf adalah adanya penyerahan, sedangkan benda yang menyatu dengan yang lain tidak bisa diserahterimakan. Tapi, perlu dicatat di sini bahwa Abu Yusuf dari kalangan Hanafiyah tidak mensyaratkan adanya penyerahan untuk benda wakaf. Di samping itu, Abu Yusuf dan Muhammad sebagai bagian dari kalangan Ulama Hana-

\footnotetext{
${ }^{5}$ Wahbah al-Zuhaely, Al-Figh al-Islami wa Adillatuhu, (Damaskus: Dar al-Fikr. 2007), Jilid 10, hlm.

${ }^{6}$ Ibid. hlm 76 .

${ }^{7}$ lbid.
} 7611. 
fiyah membolehkan wakaf benda bergerak dengan alasan benda tersebut menyertai tanah (benda tidak bergerak) seperti alat-alat pertanian, sapi dan hamba sahaya yang mengurusnya; atau karena ada nash seperti wakaf senjata dan kuda; atau karena 'urf seperti wakaf buku, mushaf, kapak, beliung, perangkat untuk jenazah, dinar, dirham, timbangan, dan perahu yang biasa digunakan usaha bagi kebanyak manusia. Hal ini atas dasar istihsan dan 'urf sebagaimana dinyatakan dalam Khabar Ibn Mas'ud: ${ }^{8}$



"Apa yang dipandang baik oleh kaum Muslimin, maka dalam pandangan Allah baik, dan apa yang dipandang buruk oleh kaum Muslimin, maka dalam pandangan Allah pun buruk."

Namun demikian, Madzhab Hanafi membolehkan wakaf benda bergerak berupa wakaf tunai sebagai pengecualian, atas dasar istihsan bi al-'urf, karena sudah banyak dilakukan masyarakat. Dalam hal ini, Madzhab Hanafi berpendapat bahwa hukum yang ditetapkan berdasarkan 'urf (adat kebiasan) mempunyai kekuatan yang sama dengan hukum yang ditetapkan berdasarkan nash (teks). ${ }^{9}$

\section{Hukum Wakaf Benda Bergerak Menurut Ulama Malikiyah}

Para ulama Madzhab Maliki membolehkan wakaf harta benda bergerak, karena menurut mereka benda wakaf itu tidak disyaratkan harus bersifat kekal. Dengan demikian, menurut mereka, wakaf itu sah meskipum untuk waktu tertentu, dan bisa menjadi hak milik kembali. ${ }^{10}$ Imam Malik mendasarkan pendapatnya kepada Hadits Shahih riwayat Ibn Umar sebagai berikut. ${ }^{11}$

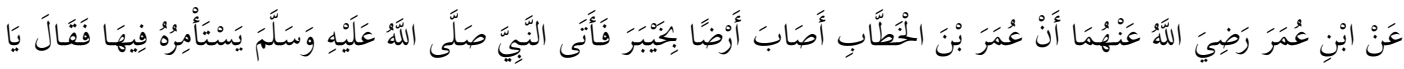

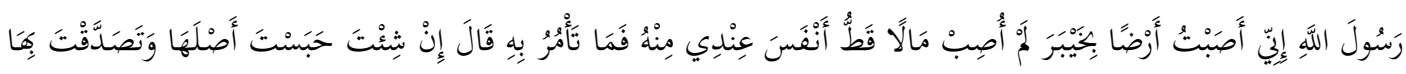

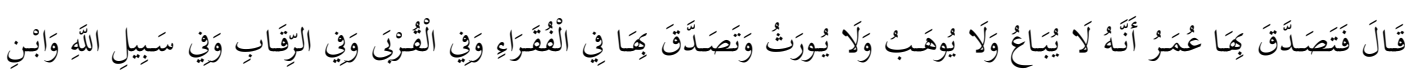

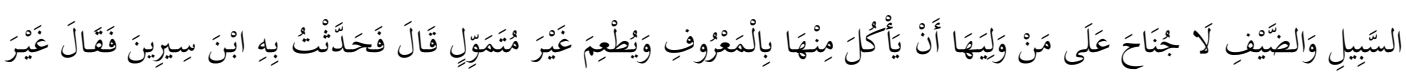

$$
\begin{aligned}
& \text { مُنَأَثِّلِ مَالًا. }
\end{aligned}
$$

"Diriwayatkan dari Ibnu Umar r.a. bahwa Umar bin al-Khaththab r.a. memperoleh tanah (kebun) di Khaibar; lalu ia datang kepada Nabi Saw. untuk meminta petunjuk mengenai tanah tersebut. la berkata, "Wahai Rasulullah! Saya mem-

\footnotetext{
${ }^{8}$ Ibnu Abidin, Radd al-Mukhtar 'ala al-Dar al-Mukhtar Syar Tanwil al-Abshar, (Beirut: Dar al-Kutub al'Ilmiyah, t.th.), Juz 6, hlm. 556.

${ }^{9}$ Wahbah al-Zuhaely, Al-Fiqh al-Islami ..., Juz 7, hlm. 162.

${ }^{10}$ Muhammad Abid Abdullah al-Kabisi, Ahkam al-Waqf fi al-Syari'ah al-Islamiyah, Alih Bahasa Ahrul Sani Faturrahman dkk. Hukum Wakaf, (Cinere Depok: Dompet Dhuafa Republika dan IIMaN Press. 2004), Cet ke-1, hlm. 272.

${ }^{11}$ Al-Bukhari, Shahih al-Bukhari, Juz IX, hlm. 263, Hadits Nomor 2532 (Versi Maktabah Syamilah).
} 
peroleh tanah di Khaibar yang belum pernah saya peroleh harta yang lebih baik bagiku melebihi tanah tersebut; apa perintah engkau (kepadaku) mengenainya? "Nabi Saw. menjawab: "Jika mau, kamu tahan pokoknya dan kamu sedekahkan (hasil)-nya." Ibnu Umar berkata, "Maka Umar, menyedekahkan tanah tersebut, (dengan mensyaratkan) bahwa tanah itu tidak dijual, tidak dihibahkan, dan tidak diwariskan. la menyedekahkan (hasil)-nya kepada fuqara, kerabat, riqab (hamba sahaya, orang tertindas), sabilillah, ibnu sabil, dan tamu. Tidak berdosa atas orang yang mengelolannya untuk memakan dari (hasil) tanah itu secara ma'ruf (wajar) dan memberi makan (kepada orang lain) tanpa menjadikannya sebagai harta hak milik." Rawi berkata, "Saya menceritakan Hadits tersebut kepada Ibnu Sirin, lalu ia berkata 'ghayra muta'atsilin malan' (tanpa menyimpannya sebagai harta hak milik)."

Karena wakaf itu sah dalam waktu tertentu, maka harta yang akan diwakafkan tidak harus kekal, abadi dan tidak dapat berubah. Oleh karena itu, dibolehkan mewakafkan (mata uang) dinar, dirham, atau makanan, dan memberikan wakaf sebagai pinjaman bagi si penerimanya, serta boleh mewakafkan pakaian atau buku-buku, menurut pendapat yang paling kuat. ${ }^{12}$ Jika harta bergerak diwakafkan untuk selamanya, maka cara untuk mengekalkannya adalah dengan penggantian. Dengan demikian, status harta bergerak ini digantikan oleh harta tidak bergerak. Dalam mewakafkan sebagian harta bergerak, disyaratkan bahwa harta tersebut bisa dipinjamkan, dan ketika dikembalikan penggantinya, harta wakaf itu tidak menghilangkan identitasnya.

Menurut Al-Dardiri ${ }^{13}$ "... masalah boleh tidaknya wakaf harta bergerak ini, seperti makanan yang tidak tentu bentuknya, kemudian jika bentuknya tidak tampak, seperti uang, maka hal itu telah memuculkan keraguan pendapat. Dikatakan, adanya keraguan itu karena bentuknya yang tidak jelas. Sedangkan, jika harta itu nyata dan jelas, maka tidak ada keraguan, dan hukumnya sah. Sedangkan, jika mewakafkan sesuatu dengan syarat bentuknya tetap, maka tidak boleh karena tidak dapat diambil manfaatnya. Bahkan, Al-Dasuqi berpendapat bahwa "Sah mewakafkan buku-buku, menurut pendapat yang paling kuat adalah sah hukum wakaf benda bergerak. ${ }^{1{ }^{14}}$

\section{Hukum Wakaf Benda Bergerak Menurut Ulama Syafi'iyah}

Imam Al-Syafi'i dan para pengikutnya membolehkan wakaf harta bergerak, seperti halnya harta tetap, karena yang menjadi dasar dalam wakaf adalah asas keabadian. Mereka menjelaskan hukum sahnya wakaf harta bergerak didasarkan atas dua landasan sebagai berikut. Pertama, kekekalan adalah standar utama dalam setiap bentuk wakaf. Dimaksud dengan kekekalan adalah selama benda itu masih ada. Oleh

${ }^{12}$ Al-Qizwiny al-Syafi'i, Al-'Azizi Syarh al Wajiz al-Ma'ruf bi Syarh al-Kabir, (Bayrut: Dar al-Kutub alIlmiyah. t.th), Juz 4, hlm.77.

${ }^{13} \mathrm{lbid}$.

${ }^{14}$ Al-Dasuqi, Al-Syarh al-Kabir, (Kairo: Dar al-Fikr. t.th.), Jilid 4, hlm. 77. 
karenannya, wakaf akan berakhir jika harta bergerak yang telah diwakafkannya itu musnah. Sebagai contoh, Imam Syairazi berpendapat bahwa "boleh mewakafkan binatang ternak, karena dapat dimanfaatkan selamanya." ${ }^{15}$ Kalimat untuk "selamanya", menurut Ulama Syafi'iyah, adalah sesuatu yang nisbi (relatif). Keabadian segala sesuatu adalah sampai batas keberadaannya dapat dimanfaatkan. Syarbini al-Khathib menjelaskan pendapat ini, dalam hukum wakaf tanah atau wakaf tumbuhan tanpa tanahnya, dengan mengatakan, "kekekalannya itu cukup, hingga dicabut setelah masa sewa habis atau kembalinya pemberi pinjaman". ${ }^{16}$

Kedua, wakaf itu tidak berakhir dengan rusaknya harta bergerak, tetapi harus digantikan dengan harta lainnya, dan penggantinya akan menempati posisi dari harta bergerak yang sudah musnah/rusak. Benda wakaf bergerak yang rusak dan dirasakan kurang manfaatnya boleh ditukar dengan benda yang manfaat dan nilai tukar sekurangkurangnya sama dengan harta benda wakaf semula. Sejalan dengan pemikiran tersebut Imam Syarbini al-Khathib menjelaskan bahwa yang paling benar adalah boleh menjual karpet dan kayu-kayu mesjid yang telah diwakafkan jika telah rusak, dan tidak dapat digunakan lagi kecuali dibakar, bahkan disebutkan menjual benda wakaf tersebut dengan harga murah untuk diwakafkan lebih baik ketimbang hilang begitu saja. ${ }^{17}$ Pendapat ini sejalan dengan pendapat yang dikemukakan oleh dua ulama besar (Muhammad dan Abu Yusuf) dan paling banyak diikuti. Berdasarkan itu, maka harga dari hasil penjualan itu digunakan untuk kepentingan mesjid. Al-Rafi'i, berdasarkan qiyas, berpendaat bahwa "seharusnya yang dibeli dari harga penjualan karpet adalah karpet sejenis, tidak yang lainnya". Al-Syairazi berkata, "Jika dikatakan, boleh dijual, maka ketetapan dari harganya adalah ketentuan nilai yang diambil dari wakaf yang musnah. Atau, dibelikan dari harga itu sejumlah harta untuk diwakafkan. ${ }^{118}$

Para ulama Syafi'iyah berbeda pendapat tentang hukum mewakafkan Dinar dan Dirham. Bagi mereka yang membolehkan sewanya, maka boleh juga mewakafkannya. Dan, bagi mereka yang tidak membolehkan sewanya, berarti tidak boleh mewakafkannya. ${ }^{19}$ Menurut ulama Syafi'iyah, benda yang diwakafkan adalah setiap benda yang dapat bermanfaat secara terus menerus baik benda tidak bergerak seperti tanah dan rumah maupuan benda bergerak seperti hamba sahaya, binatang ternak, alat-alat perang (pedang, kendaraan, dan sebagainya). Sedangkan benda yang habis dengan dimanfaatkan seperti makanan (habis ketika dimakan), wangi-wangian (habis ketika diisap) maka tidak boleh diwakafkan. Berbeda dengan tanaman yang diwakafkan untuk diisap wanginya, kayu wangi, minyak misik yang manfaatnya dengan diisap, menurut

\footnotetext{
${ }^{15}$ Imam Syairazi, Al-Muhadzdzab, (Kairo: Dar al-Fikr, th), Jilid 1, hlm. 440.

${ }^{16}$ Syarbini al-Khathib, Mughni al-Mukhtaj, (Kairo: Mushtafa Halabi. t.th.), Jilid 3, hlm. 378.

${ }^{17}$ Ibid., Jilid 2, hlm. 392.

${ }^{18}$ Imam Syairazi, Al-Muhadzdzab, Jilid 1, hlm. 445.

${ }^{19}$ Syarbini al-Khathib, Mughni al-Muhtaj, Jilid 2, hlm. 392, dan Imam Syairazi, Al-Muhadzdzab, Jilid 1,
} hlm. 440 . 
Imam Khawarizmi dan Ibnu Shalah boleh diwakafkan, karena bendanya tetap ada dan tidak habis. ${ }^{20}$

Mengenai wakaf anjing, ulama Syafiiyah berbeda pendapat sebagaimana disebutkan dalam al-Muhadzdzab ${ }^{21}$

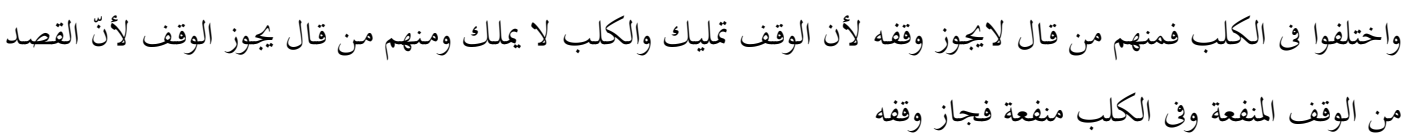

"Mereka berbeda pendapat tentang wakaf anjing. Diantara mereka ada yang tidak membolehkan karena wakaf adalah proses pemilikan benda, sedangkan anjing tidak dapat dimiliki; dan di antara mereka ada yang membolehkan karena tujuan wakaf adalah mendapatan manfaat dan ajing itu ada manfaatnya maka boleh diwakafkan".

Dalam masalah ini, Imam Nawawi menegaskan bahwa menurut pendapat yang paling rajih (kuat), wakaf anjing yang terlatih tidak sah, karena wakaf pada dasarnya adalah proses pemilikan benda, anjing bukan benda yang dapat diserahkan kepemilikannya. Imam al-Subki memiliki pendapat yang sama bahwa wakaf anjing tidak sah walaupun anjing tersebut dapat dilatih. ${ }^{22}$

Para Ulama Madzhab Syafi'i berbeda pendapat tentang hukum wakaf benda bergerak berupa uang. Perbedaan ini dapat dikelompokkan menjadi dua kelompok. Kelompok pertama yang disponsori oleh Al-Bakri mengatakan bahwa Madzhab Syafi'i tidak membolehkan wakaf tunai, karena Dirham dan Dinar (uang) akan lenyap ketika dibayarkan sehingga tidak ada lagi wujudnya. ${ }^{23}$ Di lain pihak, Abu Tsaur meriwayatkan dari Al-Syafi'i tentang kebolehan wakaf Dinar dan Dirham. ${ }^{24}$ Perbedaan pendapat ini pada dasarnya dapat dikompromikan bahwa ketidakbolehan wakaf tunai itu dihawatirkan bahwa dengan dibelanjakan, uang akan hilang (wujudnya), namun apabila melihat perkembangan sistem ekonomi dan budaya transfaransi dan akuntabel dalam suatu perusahaan atau lembaga keuangan Syari'ah, maka wakaf uang lebih memungkinkan untuk dijadikan modal usaha atau investasi dalam wujud saham atau deposito yang keuntungannya dapat dimanfaatkan untuk kepentingan umat sehingga sebaiknya wakaf uang itu diperbolehkan.

Sebenarnya, jika dianalisis secara mendalam, prinsip kebolehan wakaf tunai didasarkan pada pemikiran bahwa uang bukan untuk dibelanjakan secara konsumtif hingga habis namun bagaimana agar uang yang diwakafkan dapat dimanfaatkan untuk kepentingan masyarakat banyak. Aspek kemanfaatan dzat (benda yang diwakafkan)

\footnotetext{
${ }^{20}$ Syarbini al-Khathib, Mughni al-Muhtaj, Jilid 2, hlm. 228-229.

${ }^{21}$ Imam Syairazi, Al-Muhadzdzab, (Kairo: Dar al-Fikr, th), Jilid 1, hlm. 440.

${ }^{22}$ Imam Nawawi, al-Majmu Syarah al-Muhadzdzab, (Bairut: Dar al-Fikr, 2000), Juz 16, hlm. 229

${ }^{23}$ Al-Bakri, I'anah al-Thalibin, (Kairo: Isa al-Bab al-Halabi, t,th.), hlm. 157.

${ }^{24}$ Mahmud Mathraji al-Mawardi, Al-Hawi al-Kabir, (Beirut: Dar al-Fikr. 1994), Juz 9, hlm. 379.
} 
menjadi esensi dari jenis benda wakaf ini; bukan aspek dzat benda itu sendiri. Dengan diaturnya tentang wakaf benda bergerak seperti uang, saham atau surat berharga lainnya dalam Undang-Undang Nomor 41 Tahun 2004 diharpkan bisa menggerakkan potensi wakaf untuk kesejahteraan masyarakat luas. ${ }^{25}$

\section{Hukum Wakaf Benda Bergerak Menurut Ulama Hanabilah}

Para ulama Hanabilah hampir sama pendapatnya dengan para ulama Syafi'iyah, yakni membolehkan wakaf benda bergerak. Mereka telah menyelaraskan antara syarat kekekalan dan bolehnya mewakafkan harta bergerak dengan syarat ada pengganti. Dengan demikian, harta wakaf itu akan berstatus kekal dan selamanya. Ibn Aqil mengatakan, "wakaf itu abadi, jika keabadiannya tidak dapat dilaksanakan kekekalannya dalam hal khusus atau dari bentuk tertentu, maka dapat dilihat dari tujuannya, yaitu asas manfaat dari harta itu yang selamanya dapat dimanfaatkan dari sisi lain. ${ }^{26}$ Secara umum, para Ulama Hanabilah tidak memungkiri pendapat para Ulama Madzhab Syafi'i yang menjadikan keabadian adalah satu hal relatif dengan bentuknya masing-masing, sebab, Madzhab Hambali juga mengatakan hal yang sama seperti Madzhab Syafi'i, dan setiap yang mereka syaratkan ini hendaknya bisa dimanfaatkan tidak dalam bentuk aslinya, seperti wakaf lilin atau makanan.

Di pihak lain, Ibn Qudamah berpendapat bahwa, "segala sesuatu yang tidak dapat dimanfaatkan, kecuali harus ditukar terlebih dahulu, seperti emas, kertas, makanan, dan minuman tidak boleh diwakafkan". Kongkritnya, mnurutnya, "setiap yang tidak dapat dimanfaatkan dengan bentuknya yang tetap, seperti Dinar, Dirham, sesuatu yang dimakan dan diminum, lilin dan sejenisnya, adalah tidak sah untuk diwakafkan, sebab, wakaf itu menetapkan unsur utama dan mengambil hasilnya. Dengan kata lain, setiap yang tidak dapat dimanfaatkan, kecuali diubah dulu, tidak boleh diwakafkan." ${ }^{27}$ Berdasarkan argumentasi ini juga, mereka berpendapat bahwa boleh mewakafkan binatang, senjata, perabotan atau perlengkapan rumah, dengan pertimbangan barangbarang tersebut dapat diambil manfaatnya dan keberadaannya tidak berubah, dan tetap seperti semula.

Berdasarkan uraian di atas, maka dapat difahami bahwa Jumhur Ulama selain Ulama Hanafiyah pada dasarnya sepakat bahwa wakaf benda bergerak (وقف المنول) diperbolehkan secara mutlak seperti wakaf alat-alat mesjid (lampu dan tikar), macam-macam senjata, pakaian dan perkakas rumah baik untuk selamanya (مؤبدا) atau sementara waktu (مؤقتا) Namun, mereka berbeda pendapat tentang wakaf uang. Ulama Malikiyah dengan tegas membolehkannya, sedangkan para ulama dari tiga madzdzhab fiqh lainnya masih terbelah lagi kepada yang membolehkan dan me;arang

\footnotetext{
${ }^{25}$ Departemen Agama RI., Paradigma Baru Wakaf di Indonesiai, (Jakarta: Direktorat Pengembangan Zakat dan Wakaf. 2005), hlm. 102.

${ }^{26}$ Al-Dasuqi, Al-Syarh ..., Jilid 6, hlm. 243.

${ }^{27}$ Ibn Qudamah, Al-Mughni ..., dalam catatan luar kitab Al-Syarh Al-Kabir, Jilid 6, hlm. 235.
} 


\section{Pengaruh Pendapat Ulama Malikiyah tentang Wakaf Benda Bergerak Berbentuk Uang terhadap Peraturan Perundang-undangan tentang Wakaf}

Wakaf benda bergerak telah dianjurkan Rasulullah Muhammad Saw. dan telah diamalkan oleh para Shahabatnya. Tapi, di Indonesia pemahaman tentang wakaf pada umumnya terpusat pada wakaf benda tidak bergerak seperti wakaf tanah, kuburan, pepohonan, sumur, bangunan mesjid madrasah dan sekolah, bahkan peraturan perundang-undangan yang dibuat pemerintah sampai tahun 1977 hanya mengatur tentang wakaf benda tidak bergerak berupa wakaf tanah milik yakni Peraturan Pemerintah Nomor 28 Tahun 1977.

Pengaturan wakaf di Indonesia setelah merdeka tertuang dalam UndangUndang Nomor 5 Tahun 1960, tentang Peraturan Dasar Pokok-Pokok Agraria pasal 5, 14, dan 49 (Lembaran Negara Nomor 104 Tahun 1960) yang peraturan pelaksanaannya diatur dengan Peraturan Pemerintah Nomor 28 Tahun 1977 tentang Perwakafan Tanah Milik. Kemudian secara teknis diatur dengan Peraturan Menteri dalam Negeri Nomor 6 Tahun 1977 tentang Tata Pendaftaran Tanah mengenai Perwakafan Tanah Milik, Peraturan Menteri Agama Nomor 1 Tahun 1978 tentang Peraturan Pelaksanaan Peraturan Pemerintah Nomor 28 Tahun 1977 tentang Perwakafan Tanah Milik dan Intsruksi bersama Menteri Agama dan Menteri Dalam Negeri Nomor 1 Tahun 1978 tentang Pelaksanaan Peraturan Pemerintah Nomor 28 tentang Perwakafan Tanah Milik Tahun 1977 serta peraturan dan petunjuk teknis lainnya. ${ }^{28}$

Semua peraturan tersebut di atas hanya mengatur tentang wakaf benda tidak bergerak. Perhatian yang sangat besar diberikan oleh Pemerintah Indonesia terhadap wakaf benda tidak bergerak, bukan berarti pemerintah tidak memberikan perhatian yang cukup pada wakaf benda bergerak. Ini adalah hal sangat wajar, karena umat Islam Indonesia memiliki asset wakaf benda tidak bergerak yang sangat luar biasa, yaitu sampai dengan tahun 2011 sudah mencapai 416.999 lokasi dengan luas tanah sekitar 2 milyar meter persegi. Dari sejumlah 416.999 lokasi tersebut, $10 \%$ diantaranya berada di lokasi yang sangat strategis dan potensial untuk dikembangkan secara ekonomi. ${ }^{29}$ Namun, baru $60 \%$ dari seluruh asset tersebut yang sudah memiliki sertifikat. ${ }^{30}$ Sampai tahun 2010, di Jawa Barat terdapat 45.428 lokasi dengan luas 50.934.155 meter persegi. ${ }^{31}$

${ }^{28}$ Farid Wadjdy dan Mursyid, Wakaf dan Kesejahteraan Umat, (Filantrofi Islam yang Hampir Terlupakan), (Yogyakarta: Pustaka Pelajar, 2007), hlm. 48-50.

${ }^{29}$ Nursamad Kamba, "Pemikiran tentang Pokok-pokok Pemberdayaan Wakaf Secara Nasional", Makalah, Disampaikan dalam Temu Konsultasi Nazhir Organisasi dan Badan Hukum pada tanggal 10 Maret 2010 di Bandung, hlm. 3.

$3^{\circ}$ Sutami, "Jumlah Tanah Wakaf Sebanyak 416.999 lokasi", Diakses dari www.suara-islam.com pada tanggal 5 Juni 2016.

${ }^{31}$ Kantor Wilayah Kementerian Agama Provinsi Jawa barat Bidang Penyelenggaraan Haji, Zakat, dan Wakaf, Tanah Wakaf di Jawa Barat, (Bandung: Kantor Wilayah Kementerian Agama Provinsi Jawa barat Bidang Penyelenggaraan Haji, Zakat, dan Wakaf. 2010), hlm. 128-131. 
Sedangkan wakaf benda bergerak dalam peraturan perundang-undangan di Indonesia baru muncul dalam Intruksi Presiden RI Nomor 1 Tahun 1991 tentang Kompilasi Hukum Islam (KHI) di Indonesia dan KMA Nomor 154 Tahun 1991 tentang Pelaksanaan Instruksi Presiden Nomor 1 Tahun 1991.

Pemerintah dan masyarakat Muslim Indonesia memberikan perhatian yang semakin baik terhadap wakaf benda bergerak, khususnya wakaf tunai ${ }^{32}$ sehingga, pada tahun 2002 lahir fatwa MUI tentang wakaf uang ${ }^{33}$. Puncaknya, pada tahun 2004 diundangkan Undang-Undang RI Nomor 41 tentang wakaf.

Harta benda wakaf dalam Undang-Undang tersebut, terdiri dari benda tidak bergerak dan benda bergerak. Benda tidak bergerak meliputi:

a. hak atas tanah sesuai dengan ketentuan peraturan perundang-undangan yang berlaku baik yang sudah maupun yang belum terdaftar;

b. bangunan atau bagian bangunan sebagaimana dimaksud pada huruf a;

c. tanaman dan benda lain yang berkaitan dengan tanah;

d. hak milik atas satuan rumah susun sesuai dengan ketentuan peraturan perundang-undangan yang berlaku; dan

e. benda tidak bergerak lain sesuai dengan ketentuan syariah dan peraturan perundang-undangan yang berlaku.

Sedangkan wakaf benda bergerak meliputi:

a. vang;

b. logam mulia;

c. surat berharga;

d. kendaraan;

e. hak atas kekayaan intelektual;

f. hak sewa; dan

g. benda bergerak lain sesuai dengan ketentuan Syariah dan peraturan perundangundangan yang berlaku. ${ }^{34}$

Pasal 16 ayat 2-3 Undang-Undang RI. Nomor 41 Tahun 2004 tentang Wakaf sebagaimana dikutif di atas terutama yang menyangkut wakaf benda berberak berbentuk uang sangat jelas merupakan pengaruh dari pemikiran para Ulama Madzhab Maliki atau yang biasa disebut sebagai Ulama Malikiyah. Wakaf manfaat sebagaimana banyak diperbincacngkan oleh para ulama dan hak-hak yang bernilai materi, pada dasarnya sudah termuat dalam pasal tersebut. Bahkan untuk penertibannya telah dikeluarkan pertauran perundang-undangan yang lebih spesifik, misalnya, tentang pener-

${ }^{32}$ Dimaksud dengan wakaf tunai adalah wakaf yang dilakukan seseorang, kelompok orang dan lembaga atau badan hukum dalam bentuk uang tunai. Termasuk ke dalam uang tunai adalah surat-surat berharga seperti saham, cek, dan lainnya. Lihat Depag RI..Pedoman Pengelolaan Wakaf Tunai, (Jakarta: Direktorat Pengembangan Zakat dan Wakaf. 2004 ), hlm. 1.

${ }^{33}$ Keputusan Fatwa MUI tentang Wakaf Uang, Jakarta, tanggal 28 Shafar $1423 \mathrm{H} / 11$ Mei $2002 \mathrm{M}$.

${ }^{34}$ Undang-Undang RI. Nomor 41 Tahun 2004 Pasal 16 ayat 2-3. 
tiban hasil penemuan, hak atas kekayaan intelektual/ hak ilmiyah, hak cipta, hak merek produksi dan hak izin produksi. Lebih dari itu, menurut hemat penulis perlu juga diadakan penertiban terhadap nilai kekayaan kitab turats, terutama kitab-kitab ulama terdahulu, dimana Undang-Undang Wakaf Islam dapat menjaga dan melestarikan hak-hak umat yang ada pada kitab-kitab tersebut dan mewajibkan kepada para penerbit mengeluarkan sebagian keuntungan dari penerbitan kitab-kitab tersebut untuk kepentingan umat. Sebab, penerbit memperoleh keuntungan besar dan tidak hanya sekali menerbitkannya. Disinilah perlunya pengawasan undang-undang dalam mengatur hakhak ilmiah. Inilah fenomena yang terjadi saat ini dikalangan para penerbit. Paling tidak, semestinya manfaat hak cipta penulisan kitab-kitab turats tersebut bisa dirasakan oleh para ulama dan mahasiswa, misalnya dengan cara memberi harga yang murah kepada mereka, menyisihkan keuntungan untuk kepentingan pendidikan dan sosial lainnya. Dari wakaf manfaat dapat dihimpun keuntungan untuk kepentingan umum seperti dari hak penggunaan jalan, jasa angkutan penumpang atau barang, jasa penyeberangan atau kalau memang semua itu menggunakan karcis, maka karcisnya bisa dipermurah karena di situ ada subsidi wakaf. ${ }^{35}$ Disamping itu, pemanfaatan tanah wakaf sekitar mesjid misalnya untuk sarana parkir, pertokoan, tempat pertemuan dsb.

Harta wakaf benda bergerak yang dikelola untuk tujuan investasi dan memproduksi barang atau jasa pelayanan akan lebih bermanfaat dalam upaya pengembangan ekonomi syariah, karena pada dasarnya "investasi adalah landasan utama bagi pengembangan ekonomi"136, melalui usaha bagi hasil atau pinjaman tanpa bunga yang sangat diperlukan oleh umat Islam. Kendala yang dihadapi masyarakat Muslim dewasa ini adalah kebutuhan mendesak yang tidak dapat terhindar dari pinjaman bank konvensional dengan bunga yang cukup besar. Pinjaman lunak dewasa ini sudah tidak ditemukan lagi. Harta wakaf benda bergerak masih belum sepenuhnya dipahami dan dilaksanakan oleh masyarakat Muslim.

Menurut penulis, wakaf benda bergerak apabila dikelola dengan baik sesungguhnya sangat potensial untuk penggalian dana dalam rangka memicu angka pertumbuhan ekonomi nasional dan dalam upaya meningkatkan kesejahteraan umat. Menurut $\mathrm{M}$. Umer Chapra ${ }^{37}$ di antara dasar utama untuk mencapai pertumbuhan ekonomi yang berkesinambungan adalah adanya tingkat tabungan investasi, kerja keras dan kesungguhan. Dan potensi ekonomi wakaf terutama wakaf tunai yang digunakan untuk investasi bisnis seperti dalam fatwa Muhammad Ibn Abdullah al-Anshari akan mampu meningkatkan pertumbungan ekonomi suatu negara yaitu dengan mentransformasikan tabungan

\footnotetext{
${ }^{35}$ Mundzir Qahaf, Al-Waqf al-Islamy, hlm. 5.

${ }^{36}$ lbid.

${ }^{37}$ M.Umer Chapra, The Future of Economics and Islamic Perspective, (Jakarta: Shari'ah Economic and Banking Instutute. 2001), hlm. 311; lihat pula Farid Wadjdy dan Mursyid, Wakaf dan Kesejahteraan, hlm. 137.
} 
masyarakat menjadi modal investasi. ${ }^{38}$ Potensi wakaf tunai digambarkan oleh Tulus dan Siswadi bahwa dari 160 juta Muslim di Indonesia, katakanlah yang bersedia menjadi Waqif 50 juta orang, dengan kemampuan setiap orang berwakaf sebesar Rp.5.000, (lima ribu rupiah) per bulan dalam satu tahun terkumpul Rp. 3 triliun. ${ }^{39}$ Ini merupakan gambaran tentang modal potensial yang dapat digali dari wakaf benda bergerak baik yang berupa uang ataupun selain uang ${ }^{40}$.

Sejarah Islam telah menunjukkan bahwa wakaf benda bergerak berupa uang sudah muncul sejak abad kedua hijriyyah sebagaimana diriwayatkan dari Imam alBukhari (wafat tahun $256 \mathrm{H}$.) yang menyebutkan bahwa Al-Zuhri (w. $124 \mathrm{H}$.) berpendapat dinar dan dirham boleh diwakafkan. Caranya ialah dengan menjadikan dinar dan dirham itu sebagai modal usaha (dagang), kemudian menyalurkan keuntungannya sebagai wakaf. ${ }^{41}$ Ini menunjukkan bahwa praktik wakaf benda bergerak sudah dilaksanakan sejak masa Rasulullah Muhammad Saw., para Shahabat dan Tabi'in. Namun demikian, wakaf benda bergerak bagi umat Islam Indonesia dirasakan asing, mereka mempraktikan wakaf terbatas pada wakaf benda tidak bergerak berupa tanah untuk kepentingan mesjid, pesantren, majlis taklim dan lembaga pendidikan Islam lainnya bahkan untuk kuburan. Sekarang, masyarakat Indonesia semakin sadar akan pentingnya wakaf benda bergerak untuk dilaksanakan.

Mayoritas umat Islam Indonesia bermadzhab Syafi'i. Akibatnya, dalam berbagai Undang-undang Republik Indonesia yang disahkan terdapat kecenderungan didominasi oleh paham madzhab Syafi'i seperti UU No. 1 Tahun 1974 tentang Perkawinan dan Peraturan Pemerintah Nomor 9 Tahun 1974 tentang Pelaksanaan UU No. 1 Tahun 1974. Bahkan, Inpres No.1 Tahun 1991 tentang Kompilasi Hukum Islam lebih tampak rujukan fiqih bermadzhab Syafi'i dalam pelaksanaan perkawinan sangat dominan. Hal ini berbeda dengan kecenderungan madzhab fiqh dalam masalah wakaf benda bergerak dimana dalam Undang-undang Nomor 41 Tahun 2004 tentang Wakaf dan Peraturan Pemerintah Nomor 42 Tahun 2006 tentang Pelaksanaan UU Nomor 41 Tahun 2004 di tengah masyarakat yang mayoritas bermadzhab Syafi'i, namun tampak terdapat penga-

${ }^{38}$ Tim Dirjen Bimas Islam dan Penyelenggara Haji Departemen Agama Rl., Wakaf Tunai dalam Persfektif Hukum Islam, (Jakarta: Direktorat Jendral Bimbingan Masyarakat Islam dan Penyelenggara Haji Direktorat Pengembangan Zakat dan Wakaf. 2005), hlm. 105.

${ }^{39} \mathrm{lbid}$.

$4^{0}$ Benda wakaf selain uang karena peraturan perundang-undangan yang dapat diwakafkan sepanjang tidak bertentangan dengan prinsip syari'ah sebagai berikut: a. Surat berharga yang berupa: 1 . Saham; 2. surat utang negara; 3 . Obligasi pada umumnya; dan /atau 4. surat lainnya yang dapat dinilai dengan uang. b. Hak atas kekayaan intelektuan yanag berupa: 1. hak cipta, 2. hak merek; 3. hak paten; 4. hak desain industri; 5 . Hak rahasia dagang; 6 . hak sirkuit terpadu; 7 . hak perlindungan varietas tanaman; da/atau 8. hak lainnya. c. Hak atas benda bergerak lainnya yang berupa: 1. hak sewa, hak pakai, dan hak pakai hasil atau benda bergerak; atau 2. perikatan, tuntunan atas jumlah uang yang dapat ditagih atas benda bergerak (PP. Nomor 42 Tahun 2006 tentang Pelaksanaan Undang-Undang Nomor 41 Tahun 2004 tentang Wakaf.

${ }^{41}$ Abu al-Su'ud Muhammad, Risalat fi Jawazi waqfi al-Nuqud, (Baerut: Dar Ibn Hazm. 1997), hlm. 20- 
ruh pemikiran dari Madzhab Maliki cukup kuat terutama dalam hal yang terkait dengan wakaf benda bergerak berbentuk uang.

\section{Penutup}

Berdasarkan pembahasan pada bagian-bagian sebelumnya dapat disampaikan kesimpulan sebagai berikut. Pertama, para ulama madzhab berbeda pendapat tentang hukum wakaf benda bergerak dalam bentuk uang. Para Ulama Hanafiyah tidak membolehkan wakaf benda bergerak karena menurut mereka diantara syarat wakaf adalah ta'bid (untuk selamanya), sedangkan dalam wakaf benda bergerak syarat ini tidak terpenuhi. Sebaliknya, para Ulama Madzhab Maliki membolehkan wakaf harta benda bergerak, karena menurut mereka benda wakaf itu tidak disyaratkan harus bersifat kekal. Bahkan, menurut mereka, wakaf itu sah meskipum untuk waktu tertentu, dan bisa menjadi hak milik kembali. Imam Al-Syafi'i dan para pengikutnya secara umum membolehkan wakaf harta bergerak, seperti halnya harta tetap, karena yang menjadi dasar dalam wakaf adalah asas keabadian. Tetapi, para Ulama Madzhab Syafi'i berbeda pendapat tentang hukum wakaf benda bergerak berupa uang dan pendapat yang paling banyak dipegangi adalah pendapat yang disponsori oleh Al-Bakri yang mengatakan bahwa Madzhab Syafi'i tidak membolehkan wakaf tunai, karena Dirham dan Dinar (uang) akan lenyap ketika dibayarkan sehingga tidak ada lagi wujudnya. Para ulama Hanabilah juga membolehkan wakaf benda bergerak, tapi mereka sebagaimana Ulama Syafi'iyah tidak membolehkan wakaf benda bergerak berbentuk uang.

Kedua, pendapat para ulama Malikiyah sangat mempengaruhi Pasal 16 ayat 2-3 Undang-Undang RI. Nomor 41 Tahun 2004 tentang Wakaf terutama yang menyangkut wakaf benda berberak berbentuk uang. Pasal itu merinci bahwa wakaf benda bergerak itu meliputi uang, logam mulia, surat berharga, kendaraan, hak atas kekayaan intelektual, hak sewa, dan benda bergerak lain sesuai dengan ketentuan Syariah dan peraturan perundang-undangan yang berlaku.

\section{Daftar Pustaka}

Asqalani, al, Ahmad Ibn Hajar. t.th. Fath al-Bary li Syarh Shahih al-Bukhari. Juz VI. t.t: Syirkah Iqamat al-Din.

Badan Pusat Statistik. 2010. "Penduduk Menurut Wilayah dan Agama yang Dianut". Sensus Penduduk 2010. Jakarta, Indonesia: Badan Pusat Statistik.

Bakri, al. t.th. I'anah al-Thalibin. Kairo: Isa al-Bab al-Halabi.

Bamualim, Chaider S. dan Irfan Abu Bakar. 2005. Revitalisasi Filantropi Islam. Jakarta: Pusat Bahasa dan Budaya UIN Syarif Hidayatullah.

Bukhari, al, Muhammad bin Ismail. t.th. Shahih al-Bukhari, Vol. 2. Bandung: Maktabah Dahlan.

Dasuqi, al. t.th. Al-Syarh al-Kabir, Jilid 6. Kairo: Dar al-Fikr. 
Depag RI. 2004. Pedoman Pengelolaan Wakaf Tunai. Jakarta: Direktorat Pengembangan Zakat dan Wakaf.

Departemen Agama RI. 2005. Paradigma Baru Wakaf di Indonesiai. Jakarta: Direktorat Pengembangan Zakat dan Wakaf.

Ibnu Abidin. t.th. Radd al-Mukhtar 'ala al-Dar al-Mukhtar Syar Tanwil al-Abshar. Beirut: Dar al-Kutub al-'Ilmiyah, Juz 6.

Imam Nawawi. 2000. Al-Majmu Syarah al-Muhadzdzab. Bairut: Dar al-Fikr, 2000, Juz 16. Imam Syairazi. t.th. Al-Muhadzdzab. Kairo: Dar al-Fikr, Jilid 1.

Kabisi, Muhammad Abid Abdullah, al. 2004. Ahkam al-Waqf fi al-Syari'ah al-Islamiyah, Alih Bahasa Ahrul Sani Faturrahman dkk. Hukum Wakaf. Cinere Depok: Dompet Dhuafa Republika dan IIMaN Press, Cet ke-1.

Kamba, Nursamad. 2010. "Pemikiran tentang Pokok-pokok Pemberdayaan Wakaf Secara Nasional", Makalah, Disampaikan dalam Temu Konsultasi Nazhir Organisasi dan Badan Hukum pada tanggal 10 Maret 2010 di Bandung.

Kantor Wilayah Kementerian Agama Provinsi Jawa barat Bidang Penyelenggaraan Haji, Zakat, dan Wakaf. 2010. Tanah Wakaf di Jawa Barat. Bandung: Kantor Wilayah Kementerian Agama Provinsi Jawa Barat Bidang Penyelenggaraan Haji, Zakat, dan Wakaf.

Khathib, Syarbini al. t.th. Mughni al-Mukhtaj. Kairo: Mushtafa Halabi, Jilid 3.

Majlis Ulama Indoneasia. 2002. Keputusan Fatwa MUI tentang Wakaf Uang, Jakarta, tanggal 28 Shafar $1423 \mathrm{H} / 11$ Mei $2002 \mathrm{M}$.

Mawardi, Mahmud Mathraji al. 1994. Al-Hawi al-Kabir. Beirut: Dar al-Fikr, Juz 9.

Muhammad, Abu al-Su'ud. 1997. Risalat fi Jawazi waqfi al-Nuqud. Baerut: Dar Ibn Hazm.

Pemerintah Republik Indonesia. 2004. Peraturan Pemerintah Nomor 42 Tahun 2006 tentang Pelaksanaan Undang-Undang Nomor 41 Tahun 2004 tentang Wakaf. Jakarta: Kementerian Agama RI.

Pemerintah Republik Indonesia. 2004. Undang-Undang RI. Nomor 41 Tahun tentang Wakaf. Jakarta: Kementerian Hukum dan Hak Azasi Manusia.

Praja, Juhaya S. 1997. Perwakafan di Indonesia: Sejarah, Pemikiran, Hukum, dan Perkembangannya. Bandung: Yayasan Piara.

Sutami. T.th. "Jumlah Tanah Wakaf Sebanyak 416.999 lokasi", Diakses dari www.suaraislam.com pada tanggal 5 Juni 2016.

Wadjdy, Farid dan Mursyid. 2007. Wakaf dan Kesejahteraan Umat, (Filantrofi Islam yang Hampir Terlupakan). Yogyakarta: Pustaka Pelajar.

Zuhaily, Wahbah al. 2007. Al-Fiqh al-Islami wa Adillatuhu. Damaskus: Dar al-Fikr, Jilid 10. 